\title{
COMPETITIVE FACET OF WOMEN DYNAMISM IN ANTHILLS OF THE
}

\author{
SAVANNAH \\ Dr. PALLAVI BHARDWAJ \\ Assistant Professor, Baddi University of Emerging Sciences and Technology, Baddi, Makhnumajra Dist. \\ Solan, Himachal Pradesh, India.
}

\begin{abstract}
The research paper aims to highlight Anthills of the Savannah as an evolutionary pathway which being overly gloomy recognizes the atrociousness of the difficulties. The reinforcement of neo-colonization, fiscal failure, unfortunate governance and warfare inflicts devastation on these plush prairies. However, the allusion of savannah denotes opulent flora, an insignia of optimism, euphoria and sanguinity for communal monetary progression convoying African freedom. OBJECTIVES: The objective of this Research Paper is to exhibit the idea of the feminine power trumping the political power. SCOPE: The paper will contribute extensively in understanding and spreading the philosophies of post-colonialism and decolonization.

METHODOLOGY: Qualitative Method.

ACKNOWLEDGEMENT

It gives me profound pleasure and honor to express my thoughtful sagacity of gratefulness and appreciation towards my respected mentor Dr. Rekha Sharma, Head, Department of English, HPU Shimla. I candidly admit the support of Dr. Sharma for allowing me space to impart shape to the argument of this paper in a specific manner. I extend my heartfelt gratitude to the library staff of HPU Shimla, IIAS Shimla and JNU Delhi.

KEYWORDS: Power Corrupts, Post-Colonialism, Neo-Colonialism \& Feminine Power
\end{abstract}

Received: Jan 17, 2020; Accepted: Feb 07, 2020; Published: Mar 13, 2020; Paper Id.: IJELAPR20203

\section{INTRODUCTION}

Achebe creates a divergent instant pertaining to his considerations on the playwright's role through Anthills of the Savannah (1987). By means of uncovering the deceptions of lackeys, bureaucrats, and the governing class in an independent nation, the prime concern of Achebe has always been to teach his fellow Africans the factual essence of life by assisting them in shed-off their spiking witlessness, delusions and presumptions executed by ill-fated suppression to foreign regulation. Corresponding to majority of postcolonial novels, Anthills of the Savannah wishes to bring societal transformation that has been established inside the Nigerian "core of reality" (100). To carry forward this chain of transformation, Achebe, as a writer has consigned his fellow writers a focal responsibility to make their citizens acquainted with the magnificent African ethnic legacy. The writer's sole motive is not to get himself occupied with realistic broadcasting but he is more anxious to change the work into a legendary text by transmuting the folks' struggle as a moment of reawakening in the similar vein as the charred anthills of the savannah has been presented as a caution as well as an assurance for the multitudes. 
Anthills of the Savannah delineated as a tussle between the philosophies of autonomy and of domination deals with civil commotion and unsteadiness of African culture wherein the malevolent of power scuffle is abolishing the very core of native society. In this work, like all other African nations, the armed forces in Sandhurst convention stand far away from the civilian culture and also do not hold any responsibility at the failure of the civilian rule leading to the situation of coup. In Kangan, the fictitious locale of the work, army with full zeal and merriment holds authority and promises the gullible proletarians to emancipate the society from all the tribulations including venality, redundancy and prejudice, but to no avail. The work in a way is an alarm to the exploitation and mistreatment of power by the neo-black chiefs, who have come to power recently and have adopted all the mannerisms of their white bosses and even their education proves a hurdle to connect them with their local residents. However, there is still that fraction of society, the intelligentsias, who consider themselves to be a vital part of the natives' life and thus, raise their voice to curb this unjust political scenario fuelling high in the nation and thus, as a social worker they educate and instill the common people with a desire to bring forth an egalitarian communal order into existence.

The text being politically orientated justifies the fact that an African politician is like a blind man who knows lone direction to move and that is directed towards him only. The military leader Sam belongs to this category of ruling elite, a replica of his white masters who believes in aggrandizing themselves at any cost without feeling an inch towards the irrevocable damage which they have done to this ethnic society. This once affluent society is now inhabited by debauched and egocentric folks who are living in their own selfish caucus.

\section{APPROPRIATENESS OF THE TITLE}

A Man of the People (1989) proves a worthy predecessor of Anthills of the Savannah because the combat to anti-national and anti-mass establishment, though with little success was started with Odili and like men, but the leitmotif of resistance gained a novel stimulus with Ikem and other Abazonians who being just citizens of African state have taken up the task of curbing savage and tyrannical decree of military regime and subsequently reviving the relations of the monarchs and their governed public. The title of Anthills of the Savannah carries symbolic connotations and is authentic in its proportions which are justified through "Hymn to the Sun":

"The trees ... become ... bronze statues so ancient that only blunt residual features remained on their faces, like anthills surviving to tell the new grass ... about last year's bush fires" (31).

The anthills denote the worthy Abazonians, the insignias of wisdom and capabilities of the lineages and civilization; the scorched heat signifying disastrous authority, fiscal catastrophe and novel governance which has withered the lush green savannahs. However, the charred anthills protruding out of the arid acreage imply the mislaid imaginings as well as the craved faiths. Conversely, most of the people who are fair in their approach towards life survived these adverse socio-political situations and prove themselves as 'the new grass' articulating about the 'last year's bush fire', the tales of the struggles and the survival of the erstwhile generations and thereby infusing vigour and charm in future generations for a thriving existence.

\section{Authority Degrades and Complete Authority Degrades Completely}

Ikem Osodi, the editor in chief of the National Gazette - the writer, the novelist - is a person of deeds, who fall a prey to the elite section of populace illustrated by wicked class of people in power. Being honest in disposition Osodi is chosen as the spokesperson of the common mass who often leads delegations to the corresponding leaders to resolve the adverse issues; 
one among was when their place was afflicted with the misfortunes of the famine. He is often seen uneasy towards the armed regime cruelties and as a remonstration liftoff broadsheet campaigns contrary to the dogmas of this unwarranted government, be it party-political, societal or sexual, but following the fate of a true nationalist, Osodi too heads towards martyrdom.

Sleaze in this present scenario has become an authorized, a vibrant and a fair sport to gain deference and eminence in the society as displayed by the lives of multitude of politicians who favour bribery, corruption and other duplicitous practices as a just way to lead a secure and stable life. Contrary to it, even the gullible masses who have been adversely affected by this evil trait endure it tolerantly only for a very unjust reason that in nearby future their turn too to fill their pockets will definitely come. The text in a way depicts Achebe's unfathomable and unrelenting anxiety about the present-day politics; particularly the usage of authority by these new set of 'black leaders' or more specifically the black apes. The onset of the text exposes Sam, the military boss and the Sandhurst-trained army officer as a mischievous sprite who is disdainfully plodding his civilian cabinet. His portrait depicts him to be an incompetent and unpleasant leader whose fate favours him to become his Excellency within no time of gaining power from the ex-colonial state which too is exemplified by crooked legislators, apathetic philosophers and dispirited multitudes. He promises the mass to provide them all basic facilties, but all in vain. On the contrary, he proves to be a leader embedded with all the evils of this neo-colonial leadership, be it fierceness or fatal strength, and instead of bringing marvels to his nation he too like his civilian counterparts exploits government machinery as a personal property only to bring laurels in his life.

The lives of the characters in the work, be it Sam, Chris or Ikem pertaining to their particular vocations depicts the contemporary phase of Nigerian society. At the beginning of their careers all of them were quite intellectual, and sympathetic, but their lives took a drastic over-turn and eventually all of them met a lethal end. Encountering the misfortunes of domination and repression portrayed by Sam, Achebe now wants to portray the sovereignty of a feminine figure, an icon of harmony, diffidence and ethical values through the character sketch of Elewa, a common female representing innocent public and through Beatrice, the current face of feminine authority, a symbol of women empowerment: a legend of Idemili.

Anthills of the Savannah tries to represent the oppression inflicted by the civilian bosses as well as their tyrannical counterpart, the army through the insight of a lore and customary myth of Idemili. Achebe, being a social reformer put his heart and mind to permeate a fresh streak of self-reliance for a livelier tomorrow in his fellow Africans who have lost all their charisma to lead a steady life because of the mischiefs of warfare faced by them. Power thus, plays a major and a vital role in governing a human life, be it social, political or economic. It has become a nucleus of every particular mortal enterprise, fate of billions and a desirable destination of every human being. In the post-war period, power has gained a tremendous magnitude exemplified through the lives of copious ruling individuals. Now the point of argument here is that of the emancipation, but emancipation from what becomes the focal point. The answer to this seemingly unresolved query is the freedom from self - freedom from temptation i.e. moving towards the path of contemplation. Still one cannot think of leading his life without talking about power, as power has become the crux of an individual's existence which is precisely stated by Russell without which the survival of humankind is impossible.

The natives' lives is still governed by these unpleasant authoritarians who promise these innocent people with a glorious future but to the contrary these affluent men in power exploit the moral loyalties of the civilization and proves a blot to the culturally and morally rich native society. Unfortunately "Authority Degrades and Complete Authority Degrades 
Completely"- heading the nation towards the deadly political tumults leading a way to counter coup d'etats, authority foul practices, civil slaying protruding out from the class skirmishes and eventually curtailing the quintessence of African communal wellbeing. The writer however, is always concerned with the principle of power, its mechanism, its operation and perceives it through the myth of Idemili, showcasing the outlook of conventional ancestry towards authority. It states that at the time of evolution too power started showing its adverse impacts by ruining the globe, thereby the almighty got furious and eventually decided to send Idemili, his daughter to witness the unpleasant temperament of authority and thus, drape around it's insolent "waist a loincloth of peace and modesty" (102).

The lore of Idemili personifies female, daughter of the almighty, a sign of poise and worth and thereby has been ascribed with an apex role of maintaining serenity and morality. The pillar of water and the burning sun - two major myths of formation and annihilation signify two diversified domains, one taking up a significant task towards attainment of a state of concord and gratification and another one turning people insane in their zeal towards acquiring power and authority. Idemili thus, emanates as a "Pillar of Water" (102), connecting the earth and the heaven.

Idemili, the insignia of the daughter of the God, is adulated in the form of 'a dry stick' by the African natives. The affluent offer their sacrifices and seek out benediction to gain "admission into the powerful hierarchy of ozo" (103), but for seeking blessings the men in authority have to come along either with their daughters or the daughters of some relations. If the daughter of the Divinity finds the seeker worthless, she approves death for the person, however, if the appeal will be ratified, the seeker will reincarnate within a gap of three years. Idemili is a manifestation of the Celestial condemnation of man's "unquenchable thirst to sit in authority on his fellows" (104); Consequently, towards the end Sam faces agonizes because of his unrestricted yearn for authority and for disregarding Idemili.

In Anthills of the Savannah, Beatrice therefore, is portrayed as Idemili who provides a therapy to the malaise of existing society and eventually counsels the future peers about the misuse and exploitation of power, thereby propagating the prime catchphrase of power as opposed to powerlessness. The theme of power is delineated by the ruling fraction, while the common man and woman of Nigeria represent the second and less significant segment of the society. Achebe though, is a supporter of women's deliverance, but here in the text he neither backs the submissive and conventional mannerisms of Elewa, nor does he support the dynamic and up-to-date ways of Beatrice, but approves a novel role for females in which this so-called second sex will be free from the shackles of psychosomatic subservience to their masculine counterpart and also from the malicious patriarchal set-up but without hampering the rich ethnic conventional values.

\section{Feminine Supremacy}

Beatrice Okoh, comrade of Ikem and Sam and lover of Chris is a clear-sighted, unprejudiced and a rational employ in Ministry of Finance. She is not an imitation of some white model but a pure feminist, a reincarnation of community celebrant who being a seer can foresee the intricacies of present political world, "I see trouble building up for us. It will get to Ikem first... He will be the precursor to make straight the way. But after him it will be you [Chris]. We are all in it. Ikem, you me and even Him". (114-115). Besides coming from a male chauvinist family, Beatrice is delineated as an audacious neo-world feminine image who simultaneously holds the streaks of traditional ethics within her. Aptly said about Beatrice and all other potent females that in society numerous situations can arise wherein "women are not ... underdogs but can take over the affairs of society" (Lindfors, Palaver 150), aiding society to shed off its foibles and eventually emerge as a proficient dwelling place. Obiechina exquisitely justifies the character-sketch of Beatrice by portraying her as a true feminine figure who does not want her masculine counterparts to help her in designing her destiny. 
She is a true leader, an egalitarian who is carrying out her duties patiently, wholeheartedly and quite proficiently without any hassle.

Tolerance is the key to the new style, in contrast to the despotism of the authoritarians. (Letter 1)

\section{Transformation- A Vital Element}

Human is a blend of various traits. All the prime characters underwent a sea change in their personalities with the passage of time. Beatrice though an influential and a self-sustaining female too carries some mannerisms wherein she is delineated as an egotistical person who use to keep a discernible distance from the common mass as exemplified through her relation with her maid Agatha. Beatrice at times behaves crudely with the maid and in reciprocation the only weapon of defense projected forward by the poor worker is that of sullen disobedience in the form of tears and sobs. It portrays a slave-master liaison more specifically of colonial era, in which only the voice of the master is heard and acknowledged as appropriately delineated by Kirpal. However, after losing her close friend Ikem, Beatrice understands the basic essence of life and thereby gets completely transformed carrying along a streak of empathy and subsequently realizing her fault tender apologizes: "The unbelief [of Agatha] turned first to shock ... then, through the mist to her tears, a sunrise of smiles" (185) gushed out.

Ikem undoubtedly carries sympathetic attitude towards poor but it was a mere superficial bond. This is represented through his insensitive relationship with Elewa; on one hand he considers that Elewa carries a special place in his life, on the other hand Ikem dragged her out of his house at midnight stating that he could not think of spending whole night with any low-class woman. Nonetheless, his assertion of this weird act is that he is guarding the poor lady from getting defamed, which seems rather dubious. Even Ikem does not feel comfortable connecting literally to the struggles of the common people. Contrariwise, Ikem metamorphoses into 'a man of the people' who now forms a connection with the struggling mass after meeting taxi drivers and an oldman from Abazon. Ikem is intensely moved by a surprise visit of taxi drivers at his house who appreciates and acknowledge him for his allegiance in sustaining proletarians through his worthy crusading sections against authoritarians in National Gazette. Even the tale of Abazonian's struggle against the potent head of Kangan too inspires Ikem to combat against the autocratic black leaders in order to guard the so-called "small people" (136). Thus, that night when those drivers landed at Ikem's house turns to be a night of contentment, alteration and his eventual alliance with Elewa denotes cerebral-commonplace unison.

One more example of the very notion of the incapacity of the elites to associate with earthly people is Chris, who like his fellow creams of the crop remains detached from the common mass. When he was compelled by his fellow authoritarians to leave Bassa, a student leader, Emmanuel helped him to flee the place under the guise of a common man. A taxi driver Braimoh, a symbol of commonality helped Chris by providing shelter in his house for certain days. These incidents prove to be a silver lining for his apt transition. Though belonging to the governing section of the society, he never feels a darn of it. He now carries a thoroughly changed persona wherein he believes that the elites do not shoulder the progress of a nation alone but it is the common gentry who too plays an equally relevant role in uplifting a nation to neo-heights and thereby supplanting despotism with democracy. His connectivity with the poor to some extent helps in reducing the gap between power and powerless which is evident from his relation with the common mortals, "Chris, in spite of his brilliance, was just beginning to be vaguely aware of people like ... old man [Abazonian]" (232), and eventually unveiling his hearty connection with humble section, Chris offers himself as a sacrifice while safeguarding the integrity of a common adolescent - 'Adamma' - and becomes an emblem of adulation for humanity. 
Thus, all these characters subsequently underwent the process of 're-edification'. No doubt all of them choose divergent pathways to lead their lives but unifies at one point for accomplishing a common goal of getting closer to the commonplace gentry and thereby working hand in hand with them in bringing laurels to the nation.

\section{Optimism- Favorable Outcome}

The unswerving scholars - Ikem, Chris and Beatrice - too encountered the hardnosed nature of authority in this afresh neocolonial African community. In their steadfast manner to counter these despotic, Ikem and Chris have sacrificed themselves in quest of their esteemed intents. Among this privileged class, only Beatrice has survived with a hope to enlighten the future generations by preaching them to follow a righteous path with a mission to keep up the spark of the struggle alive and eventually attain zenith. Therefore, the text suggests that a woman should be given equal rights and opportunities in all walks of life as her counterpart does, who will work hand in hand with men, even surpassing her masculine counterpart too beyond her physical capabilities and will prove a boon in retrieval of a society's and foremost the nation's mislaid identity and distinctiveness.

Ikem, being the work's notable rationalist does not believe in woman forte; no doubt he often pens down his articles against suppression but he never talks or writes about the worthiness of a feminine figure even while drafting a full-length novel on Women's War of 1929, which depicted a demonstration projected by numerous Nigerian females in order to curb the anecdotes of the government against imposing tax on African women. Beatrice, a stern admirer of Ikem's crusading pieces, becomes disenchanted over his reluctance to give apposite privilege to feminine expression, "no clear role for women in his political thinking" (91). But after dissonance with His Excellency, when he was suspended from the National Gazette, Ikem realizes that Beatrice was every inch correct in displaying his averseness towards women and women power in his works. However, Beatrice comprehends his non-expressive version towards females as not a manifestation of his peculiar feebleness but a mark of social regression in Africa, even amongst the reformists, the elite section who are considered as a ray of communal justice and sanguinity.

And I understand the meaning of his despair too ... a man, who has written a full-length novel ... on the Women's War ... which stopped the British administration ... But ... giving women today the same role which traditional society gave them of intervening only when everything else has failed is not enough ... like the women in the Sembene film who pick up the spears abandoned by their defeated menfolk. (91-92)

Therefore, a female should not be considered as a mere displaying article, a show-piece but instead she should be granted an earnest pedestal to exhibit her abilities as well. Even females today are working shoulder to shoulder with men and at times ahead of men too, thereby this feminine power should not be under-estimated and should not be considered as a last recourse.

The hopefulness thus, transpires from the amalgamation of two deviating sections of the society viz. the intelligentsias and the labor force during the baptism ceremony of Ikem-Elewa's infant. This conventional naming ritual accentuates the resilient longing to reconnect to the trampled rich African heritage and thus in a way all the patrons - be it philosophers, proletarians or the bureaucrats - assembled together symbolizing the prospects of an affluent African future. Showcasing the path of progress and thereby bestowing equal status to females, the baby girl is given a boy's name "Amaechina: May-the path-never-close.... The Shining Path of Ikem" (222). The baby is named in gratitude of her deceased father Ikem; in that way it will imply extraordinary potentials for reclamation and replenishment. Amaechina 
thus, emerges as a neo-generation Afro youth grooming in the universal rural dwellings and catching hold of superfluous probabilities and ventures for accomplishment of her goals of reaching apex.

Even Beatrice's mid name Nwanyibuife - "A female is also something" (87) - carries ample of connotations too. Thus, in a way - 'Nwanyibuife' and 'Amaechina' - both advocates the prominence of the most unloved and abandoned being, 'Women' - who in a similar vein like the poor proves irreplaceable and precious for any communal cause, despite unequal rights and opportunities. The text therefore delineates women at par with men in all respects as exemplified beautifully by Achebe.

We must ... find a way in which the modern woman in Africa ... bring her ... special gifts to the running of affair. This is one of the things ... I was tentatively exploring in Anthills.... It's not enough for men to work out what women should do.... Women should ... not just from a copying of European fashions ... but out of our own tradition ... work out a new role for themselves. (Qtd. in Lindfors, Palaver 150)

The spirit with which the naming ritual is pre arranged by Beatrice is exceedingly appreciated by Elewa's uncle, "... in you young people our world has met its match" (227), portraying Beatrice as one among those progressive individuals who are quite determined to lead a life of their own, analogous to a mother-bug who believes in an incessant struggle for subsistence. The mother-bug emboldens her young ones not to get perturbed by the hot water drizzled on them and asserts that to survive one has to be bold enough to cope with every adverse situation and credits it to be the only rule of survival, so: "Don't give up, whatever is hot will become cold ... And so they survived" (199); thus, exemplifying Darwin's principle of 'The Survival of The Fittest'.

\section{CONCLUSIONS}

The focal point which Anthills of the Savannah ponders upon pertains to the matter of curbing the tyranny of the oppressor. The tale "The Tortoise and the Leopard" exemplifies the scuffle between the Abazonians and the army which indubitably results into the triumph of the military, however, the footprints of the weak on the combat ground substantiates as an insignia of potency for the successors, who will for sure imbibe courage and strength from the fervor and zest of their forefathers and will unquestionably wage a battle against the repressors and will subsequently let their authoritarians taste their mettle. Amaechina, a neo-African thus, emerges as a novel successor who will bring sanguinity to this desolate savannah with the assistance of integral gathering who have come to witness her baptism, signifying newfangled grass, a ray of hope for the jutting anthills, the natives, who are battling the sweltering drought, the subjugation. Consequently, Anthills of the Savannah provides a therapeutic touch besides an empathetic or a sympathetic one to the inhabitants' warped psyche with a high responsibility shouldered upon female characters, who are pertinent blends of customary ethics and robust metropolitan ideals. This merger will certainly take the nation-state to pinnacles by envisaging the impending perils and jeopardies, and eventually coming up with the resolution of establishing a utopic realm.

\section{REFERENCES}

1. Achebe, Chinua. A Man of the People. 1966. New York: Anchor, 1989.

2. Jahan, Mursalin. "Expressive Individualism in the Nineteenth Century Patriarchal Creole Society: A Study of the Portrayal of Edna Pontellier in Kate Chopin's the Awakening." International Journal of English and Literature (IJEL) 7.2 (2017): 65-74.

3. Anthills of the Savannah. 1987. London: Pan, 1988. 31, 87, 91, 92, 100, 102, 103, 104, 114, 115, 136, 185, 199, 222, 227 and 232. 
4. Ahmed, Tanvir. "Impacts of agricultural commercialization on smallholder farmers in south-western region of Bangladesh." International journal of economics, commerce and research 7.2 (2017): 33-40.

5. Kirpal, Viney. "Anthills of the Savannah: Postmodern or Postcolonial Novel?" South Asian Responses to Chinua Achebe. Ed. Bernth Lindfors and Bala Kothandaraman. New Delhi: Prestige, 1993.

6. Meem, Fahmida. "The Expected Gender Performance, Subversion of it, and Post-Colonial Discourse in the Grass is Singing." International Journal of English and Literature (IJEL) ISSN (P) (2016): 2249-6912.

7. Lindfors, Bernth, et al., ed. Palaver: Interviews with Five African Writers in Texas. Austin: Africa and Afro-American Research Institute UP, 1972. 150.

8. Dasgupta, Pritha. "Women alone: The problems and challenges of widows in India." International Journal of Humanities and Social Sciences (IJHSS) 6.6 (2017): 35-40.

9. Obiechina, Emmanuel. Letter. N. P. 1 .

10. Fahmi, Marwa Essam. "Helen Recorvits's and Gabi Swiatkowska's My Name is Yoon (2003): A Postcolonial Picture Book of Asian American Child's Journey Into Assimilation and Heterogeneity." International Journal of English and Literature (IJEL) $\operatorname{ISSN}(P)$ (2016): 2249-6912.

11. Russell, Bertrand. Power: A New Social Analysis. 1938. London: Unwin, 1960.

12. Ahmed, Charan Iftikhar, Wang Bang Hu, and Suneel Kumar. "Indigenous knowledge about prediction in climate change." International Journal of Humanities and Social Science, 5, 4562 (2016).

\section{AUTHOR PROFILE}

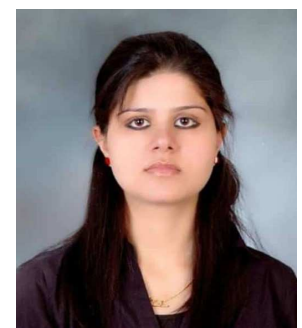

Dr. Pallavi Bhardwaj, is working as Assistant Professor English in Baddi University of Emerging Sciences and Technology Baddi (Dist. Solan, Himachal Pradesh). She hails from the same small town Palampur. She did her schooling from St. Paul's Senior Secondary School Palampur, Bachelor's in Science from CSKHPKV (Himachal Pradesh Agriculture University) Palampur and her Masters in English, M.Phil. and Ph.D. from Himachal Pradesh University (HPU) Shimla. She is having teaching experience of more than 8yrs. During this specified period she worked at UIIT (HPU) Shimla, Lovely Professional University (LPU) Phagwara Jalandhar and at Baddi University of Emerging Sciences and Technology Baddi (Distt. Solan, Himachal Pradesh). She has also published around 9 research papers and has attended various seminars, workshops and colloquiums. She is a bibliophile having keen interest in African Literature. 